\title{
Digital Piety in Bangladesh: A Psychosocial Analysis
}

\author{
Md. Sayeed Al-Zaman*
}

\begin{abstract}
Following social development, Bangladesh has become more welcoming to digital technologies. Thus, an impactful digital community is flourishing within the country. It has been thought online community would be a sub-culture and mere clique. However, proving this surmise wrong, netizens constitute half of the country's entire population in Bangladesh. As digital neighborhood is becoming larger as well as second-home to its users in Bangladesh, so the interaction and discourse is growing at an incredible pace. What we now call online is nothing but a reflection of offline except its physicality, where, like other real-life contents, religion has also been accommodated. Religion in cyberspace is dubbed as "cyber-religion". Netizens perform virtual religious practices, express emotions regarding their religion, and participate in discussion. Debates on religion often leads to the intention of malice, and contending faiths transform peace into communal animosity. Thus, society get heated by hostile communal performances. In contemporary Bangladesh, "digital piety" as an exclusive phenomenon attained immense social significance. Investigating the dynamics of digital piety and its psychology, this study presents an overview of the mechanism of digital religion, and interactive relationships between online piety and communal tension on socio-political context.
\end{abstract}

Keywords: Islam, society, religion, Bangladesh, digital, communalism, internet, politics.

\section{Introduction}

It has been said humorously that there is no evil in cybersociety as everyone appears to be so benign in their online profiles and discourses. In theory, the propensity of pretending to be "someone else" or incognito by negating and/or adapting certain characteristics concurrently in virtual space where only a few people truly know the individual in real-life is often addressed as the "construction of identity" (Jordan, 1999). Through this easier route, thief could be charitable and murderer might seem humane in cyberspace under a pseudo-identity. Bangladesh is experiencing an intense influx of virtual inhabitants from the last decade. Five key reasons are backing up this extraordinary technological transformation ab inito: (a) increased individuals' income so do their affordability of digital devices; (b) increased digital literacy that let individuals to comprehend the functions of digital devices; (c) expanded

\footnotetext{
* Md. Sayeed Al-Zaman is a researcher of Digital Sociology, currently serving as an Executive Editor in Advanced Services for the People's Economy, Culture and Technology (ASPECT) Trust. Email: ovi.sayeed@yahoo.com
} 
technology market following the demand which offers a plethora of digital apparatuses and services; (d) scopes of wide as well as intense sharing and building bigger communication network than the traditional communicative platforms; and (e) massive resource of information and rooms of alternative activism. Statistics present the exact scene of this tremendous paradigm shift. In 2008, the number of internet users were 22.95 million which soared extremely and reached at its acme in 2018 with 92.47 million users (BTRC, 2018).

However, a considerable metamorphosis has been experienced in Bangladesh online climate from the last few years, and a new wave of piety is emerging in cyberspace which is othering the smaller religious communities in Bangladesh. In such circumstances, Islam has emerged as the most dominant religion disregarding three other minor religions: Hinduism, Buddhism, and Christianity in contemporary Bangladesh. In practice, this seemingly recently developed digital piety is not new rather is an inevitable outcome of a long religious legacy that was dwelling and playing effective roles in prior physical public sphere. On the other hand, some motives and logics of digital piety are the indications of deep-rooted religious politics and faith-business enacted by multiple interest groups. In this regard, political Islam in Bangladesh often is considered the central weapon.

Nevertheless, Bangladesh digital public sphere is going to face a new crisis in regard of religious fanaticism based on cyberspace. Unless the radicalization of digital public sphere has been put on a hold, the coexistence of religious communities will be at stack. Yet, no endeavor has been seen among intellectual arena to investigate this swelling tendency of digital piety and recommend the plausible solution to mitigate the predicament. Besides, overt and covert nature of newly formed and ballooning online religious community is out of consideration of the authorities. In practice, such digital cliques of devotees bear some unique features which might threaten the social peace and congruence. Therefore, this qualitative analysis discovers the mechanism of faith-business in digital platform, the psychology of digital piety, its social impact, and the interrelationships between communalism and digital piety in context of contemporary Bangladesh.

\section{What is Digital Piety}

Theorists use the term "cyber-religion" or "online religion" to signify new types of religious community and ritual, and demonstrate a new emerging alliance between computer technology and religion as people are bringing their spiritual lives into cyberspace (Bauwens, 1996). Beginning of the internet is also the sprouting period of online based religious activity 
date back in 1980s. Within the next four decades, the major world religions have found out their new virtual but more effective nest in digital atmosphere. Online platform has become the single hub of religious people: Christians, Buddhists, Hindus, Judaists, Muslims, and irrespective to their religions, they participate in "holy" discourses and virtual feud (Campbell, 2010).

Nietzsche, addressing the God as a has-been, committed a mistake (Nietzsche, 1974). As hybrid technology and cyber communication is mushrooming around the world from the last two decades, a seed of digital piety has been implanted and is being amplified hastily. Consequently, the omnipresence of "digitalized God" in people's lives is budding. Even the religious institutions are also following the devotees in online. Myriad evident and clandestine religious communities have formed into cyberspace and religious establishments are swiftly going virtual. Ecunet (Christianity), H-Judaic (Judaism), BuddhaNet (Buddhism), Renaissance (Islam), etc. are the examples from 1990s cyber-religion portals (Campbell, 2010). Islam as a dominant one has recently been transformed into cyber-religion and started surpassing the others in terms of its impact, expansion, and population. Gary R. Bunt (2009) states:

Specific forms of online or digital Islam, distinct from offline or analogue Islam, have developed. A place of religious instruction may only exist in a virtual context. A network or community may only gather online. Their name may not have areal- world equivalent. (Bunt, 2009:01)

What religious people do in cyberspace and what are their motivation to be here negating offline demand careful examination. Digital media provide greater flexibility in communication with others and more opportunity to find like-minded people with less efforts. On the other hand, a larger online community, whose members are connected through the conduit of internet, is relatively easier to form than in real-life setting. Therefore, religious websites full of spiritual contents, digital religious institutions (e.g. virtual church, mosque, pagoda and temple), and religious devotees filled with both piety and zealots have constituted a new digital religious climate in online. The accumulation of online religious activities and the expression of faithfulness in such online environment is called "digital piety".

\section{Digital Piety in Bangladesh: A Sociological Investigation}

Where scarcity of resources is higher, unlawful activities surge. Although economy of Bangladesh was almost stable for more than a decade in the running century, and the GDP is 
thriving in the last four consecutive years, from 6.061 per cent in 2014 to 7.284 per cent in 2017 (World Bank 2018), income inequality between rich and poor is snowballing. According to Bangladesh Bureau of Statistics (BBS), the income share of the poorest five percent of our population fall from 0.78 per cent in 2010 to 0.23 per cent in 2018 in terms of overall income, whereas the richest five per cent experienced a growth of income from 24.61 per cent in 2010 to 27.89 per cent in 2018 (Ahsan, 2018).

Alongside this broad tendency in Bangladesh national economic climate, a sharp expansion of middle-class community has been taking place amid society. Bangladesh Institute of Development Studies (BIDS) shows that middle-class population rose from 7 per cent to 35 per cent in only two decades (Daily Sun, 2018). Among this vast number of rapid growing middle-class income population, two strong and significant inclinations are palpable: (a) technological proclivity; and (b) religious proclivity. Both are getting superfluous in growth, and both combining to each other, give genesis a unique phenomenon: use of digital technology in religious purpose.

Technological proclivity: Why middle-income people are becoming more prone to technology has explanations on both local and global perspective. The world is becoming more centralized and globalized in terms of economy, culture and information-flow after the so- called $4^{\text {th }}$ Industrial Revolution in the second half of the last century. Inception of internet and digital communication technologies have revolutionized the prior human interaction and communicative milieu. Communication contents, such as text and speech along with the communicator have been shifted from offline to online. Every development has few routes. Of them, Diffusion of Innovation as theory as well as idea in the dissemination of digital technology is appropriate to the context of Bangladesh.

The theory proposes that no idea, even having apparent advantages, is easy to adopt and spread in a society at a glance. Rather, it takes time and strategies. Five categories of people are involved in this process of idea distribution and adoption: innovators, early adopter, early majority, late majority, and laggards (Rogers, 1983). What we are observing in Bangladesh nowadays is with increased income and purchasing capacity, people are going for digital devices and buying new communication services: internet, smartphone, computer, tab, VR, etc. Although Bangladesh has almost no innovator of digital devices, however, the affluent and ballooning middle-class people are acting as the early adopters and early majorities respectively according to their income, literacy, access, and social status. Thus, the total 
number of netizens are skyrocketing every consecutive year, and the rate of users reached at 18.25 per cent of the entire population in 2016 from merely 1 per cent in 2006 (World Bank, 2016).

Religious proclivity: To define the nexus between religion and social class, more precisely the economic one, has been a polemic issue. Karl Marx addressed religion as "the opium of people" in his famous euphemism, and these people are the working-class or proletariat (McKinnon, 2005). On the other hand, Max Weber (1949) argues certain classes and status groups work as the carries of certain kinds of religions: early Islam was carried by conquering warrior, Christianity by nomad and urban artisans, and Confucianism by literate elites Therefore, religion has a deep reciprocity between certain classes, and some social classes have little business with spirituality. Determining this relationship is problematic because this delicate interconnection varies from society to society. Even religious belief, practice and intensity do not solely rely on socio- economic conditions, rather other crucial factors including biological and political influence, and highly varies from person to person within a community. Therefore, to propose a general overview would do the work.

Bangladesh populace can be categorized into three traditional economic tiers: upper-class or affluent, middle-class or moderate, and lower-class or poor. By nature, upper-class affluent community is more open to Islam as the dominant religion in Bangladesh. Middle-class is more-or-less conservative regarding merely religious rituals. However, to specifically mention these population is imperative here because of their strong explicit religious fervor and worship-attendance tendency not only in present-day Bangladesh but also elsewhere (Jones, 2015). The lower income people, however, not rigidly maintain religious customs although cultivate deeper belief than the other two tiers.

Meanwhile, people who parent religious zealots and the key actors of communal dissatisfaction within the country are shifting into cyberspace, and causing communal disharmony even in online. But why religious upsurge in "secular" Bangladesh? Is this really a secular country by its expressions? To explore the answers and successfully comprehend the nature, extent and dynamics of digital piety in Bangladesh, which a poverty-stricken and a fertile ground of Islamic extremism for several years, the religious legacy of this region should be examined under the light of an abridged version of history, and needs to analyze the contemporary "secularism vs Islamism" condition to measure the intensity of digital devoutness. 


\section{Legacy of Islam in Bangladesh: A Brief History}

History of Islam as a dominant religion in this region is more than thousand years old. Contemporary religious practices of Bangladesh are shaped in two specific periods, and in practice, both were in fact colonial eras: British Raj is the direct and explicit colonial power, whereas and Pakistan regime was the quasi-colonial epoch. Therefore, the version of Islam during both periods was more politicized and attributed than spiritual and customary one. Besides, after liberation, the essence and course of Islam in Bangladesh has been changed several times. Hence, to track the route of Islam in Bangladesh, sketch the complete scene of its evolution, and contemporary aptness toward digital piety, a study of these periods is imperative.

Colonial regime: The outset of 190 years long British rule in Indian subcontinent was started right after the defeat of Nawab Siraj ud-Daulah in 1757. To sustain their stronghold in this foreign soil, British needed some extraordinary ideas to create chasm, and they succeeded by promulgating "Divide and Rule" policy along the sensitive religious fault line between two major religious communities of the subcontinent: Hindu and Muslim (Xypolia, 2016). After the Sepoy Mutiny in 1857, the estrangement and contestation of two religious sects were overt. Thus, a series of violence and protests was unleashed, all the peace accords became futile, and thereafter, the omega of British rule had finally come in 1947 through a decisive partition.

Based on Jinnah's "Two-Nation Theory" which gained mass support from the Muslim population of the subcontinent, two full-fledged country came into being after the partition: India for Hindus and Pakistan (East and West) for Muslims. However, fervor of East Pakistanis, who voted on religious segregation of the greater India, had evaporated experiencing the oppressive rule of West Pakistani leaders. Although religion played a key role in dividing the region, but economic oppression came forward that consequently dictated the East Pakistanis to wage a blood-strained battle in 1971 against West Pakistan in order to be separated and form a new liberated nation-state.

Post-colonial era: Bangladesh religious environment has continuously been misunderstood and misinterpreted as "secular" by the intelligentsia that the separation of East and West Pakistan was also a religious one, and they belittle the covert economic reason which was in fact the driving force behind the Liberation War. Six-point Program is considered as the pivotal manifesto of a liberated Bangladesh. However, among these six demands, three were 
economic (point 3,4 and 5), two were related to governance (point 1 and 2), and another is regarding security (point 6). Even no mention of secularism or religion was found in two preceding and following influential manifestos namely Twenty-One Point Program of Joint front in 1954 and Eleven Points Program in 1969 by The All-Party Student Action Committee (Banglapedia, 2018). Therefore, the entire population has no prior idea as well as business with secularism till then, so they whole-heartedly supported and complied with the movement.

However, the flawed idea has two major explanations: (a) after repatriation, Tajuddin Ahmed declared democracy, socialism, and secularism will be the base of the new country (Hasan, 1986). Afterwards, four fundamental principles (democracy, socialism, secularism, and nationalism) were included into the constitution of 1972 (Government of Bangladesh, 1972). (b) Populace of Bengal was inasmuch as constituted with impoverished people who were more-or-less secular in nature and supported secular Krishak Proja Party (KKP) too led by A. K. Fazlul Huq (Chatterji, 1994), and even participated in Liberation War irrespective to race, ethnicity and religion. However, both conjectures are, to some extent, blemished. No socioreligious investigation on Bangladesh faith-community was conducted after the liberation. In fact, no one asked the citizens if they were willing to keep pace with Islam and wanting their country to become secular. Therefore, strong religious essence is still dwelling amid the Bangladesh society that we discern on a regular basis. According to Hossain (2012):

Since the 1940s nationalist leaders have used both Islam and Bengali ethnicity for the purposes of political mobilization-the former to mobilize Bengali Muslims during the Pakistan movement in the 1940s, the latter during the autonomy movement of the 1950s and 1960s to mobilize Hindus and Muslims alike. When Bangladesh gained independence from Pakistan on 16 December 1971, Jinnah's 'two-nation theory', the basis for the creation of Pakistan, was pronounced 'dead' [...] However, Bengali ethnicity soon lost influence as a marker of identity for the country's majority population, their Muslim identity regaining prominence and differentiating them from the Hindus of West Bengal. (Hossain, 2012:165-198)

Often, religious sentiment was ignited by and as part of strategic governmental promulgations. In 1977, for an instance, Ziaur Rahman included Bismillah-Ar-Rahman-ArRahim ('in the name of Allah, the Beneficent, the Merciful') and 'absolute trust and faith in the Almighty Allah' should be 'the basis of all actions' removing ideal of secularism in the constitution (Majumdar, 2016). Few years later, Hussain Muhammad Ershad endorsed (in Article 2A) Islam as the state religion by the Eighth Amendment of the constitution in 1988 (CLCBD, 2011), which deliberately curb the rights of other religious sects. Therefore, 
religious sensationalism and zealots are still residing among publics in modern-day Bangladesh, and incessant conflicts between seculars along with religious minorities and Muslim communalists have been staging.

\section{Religious Population, Communal Environment and Digital Media}

Social negation of Islam did not happen in Bangladesh, rather it has been penetrated in almost every aspect of national and individual life. Therefore, secularism received a great failure here. In contrast, as a reaction of profound and ballooning atrocities against religious minorities, a huge shift is apparent in contemporary demographic nature of Bangladesh. Digital media- initiated violence from the previous few years is consistently taking place around the country. Since 2012 in Bangladesh, from when online community started getting bigger at an unimaginable pace, political Islam as a dark side of digital piety has been germinated into cyberspace and force to collapse the communal harmony within society. Preprogrammed communal hatred was begun to disseminate via online platforms to a great extent. The consequences are abysmal, and religious minorities have been becoming marginalized even in online.

Muslims constitute the largest portion (90.39\%) of total population in Bangladesh, according to the National Population Census 2011. Change in Bangladesh religious demography is very subtle though significant. Since 1981, Muslim population increase almost 4 per cent, whereas Hindu population, the largest religious minority, reduced at the same rate till 2011 (BBS, 2015). Therefore, it has been hypothesized that the ongoing exodus of Hindu population from Bangladesh to India after the partition as well as the liberation war is a consequence of Islamic zealots, which will have an appalling impact on Hindu demography in Bangladesh (The Hindu, 2016). Contribution of digital piety in making religious minorities as psychological refugees is galore. Thereupon, understanding the nature of digital denizens and social psychology of their piety is essential.

\section{Digital Immigrants and Digital Natives: Pattern of Piety}

Two relatively new terms in digital era: digital immigrant, and digital native were coined by Marc Prensky to draw a demarcation line between generations based on the usage of digital technology. According to him, digital immigrants are the people who born before digital age, grow up and then learn the use of digital technology, and often resist or unwilling to do so. On the other hand, digital natives are born in digital age who grow up using digital technologies and embrace them heavily. In developed countries, the dividing year, as it has 
been proposed, is 1985 (Prensky, 2001). Although in Bangladesh, digital technology penetrated after 1990s, and therefore, most of the young people in this generation, who constitute largest portion of the online dwellers, are digital immigrants by nature. Interestingly, they are having more similar characteristics with digital natives, the new age users of digital media, than divergences in terms of adoption and adaptation capabilities.

To investigate the religious status of Bangladesh young generation, like other religions, Muslim youths have been found highly pious and becoming more prone to Islam than their previous generations. Although some of them are irregular in religious practices and rituals, however, they have firm believe in religious doctrines. A study shows 96 per cent, 89 per cent and 86 per cent youth considers regular prayers, reading sacred texts, and fasting highly important religious activities respectively. In contrast, they have more wide view toward other religions and women rights (Garner, Yasmin \& Aziz, 2012). Another study shows the growing religious orthodoxy among university students, who are the most advanced portion of Bangladesh digital media users, due to several driving forces including frustration, loneliness, drug addiction, lack of proper vision and guidance, and at times affluence (Jamal, 2017). Therefore, it is fathoming that these youths would act a pioneer and harbinger of Islam and circulate religious homilies posing pious in digital platforms as well. Apart from youth, the adults, who mostly are digital immigrants, have indifferent role and pattern in participating religious discourse in digital public sphere.

\section{Social Psychology of Digital Piety}

Religion, since the history of human cognition, has emerged as a solid psychological force. Needless to say that every religion has a significant appeal to its followers, and major religions provide with a complete code of conduct. Although, individuals are simultaneously sovereign and depended by nature, they, perhaps, would love to be confined into an attributed framework. Generosity and cruelty both depend on religious belief and how it is being used upon individual. Siding the humane incidents of religious belief, it has also been emphasized on religious politics and its grave consequences, such as Iraq, Indonesia, Bosnia, Rwanda, Sudan, Afghanistan, etc. A new religious game has started in cyberspace from the last few decades which we called as "digital piety". Investigating the psychology of digital pious, in needs to explore at first that what faith contains and how it works on a person dissecting religious sermons and discourses.

How religions succeed: Following the rule of rhetoric given by Aristotle, every religion too 
functions with the three key actions: logic, emotion, and fear (Griffin, 2012). Religious rhetoric at first pursue the potential followers to do or not to do something by promulgating this is right and this is wrong backed up by logics. To strengthen the implemented code of conduct, then religion use emotion to influence the behavior pattern of the cohorts. Afterwards, fear appeal posits that if they do not do such according to the manuscript, the consequence would be terrible. According to the synthesis of the ideas of Bertrand Russel and T. S. Eliot (Russel, 1996), religious fear can be categorized into two types: (a) This World or mundane fear that threatens individual as follower to be more devotee otherwise they would have ended up in isolation and criticism which people fear; and (b) That World or afterlife consequences that remind religious man to be faithful to his God or else he would be deprived from heaven (Carlisle, 2013). Thus, champions of religions (in the case of Islam in Bangladesh, the preachers are Imam, Mullah, Huzur, Pir, etc.) motivate the potential acolytes to follow the religious code of conduct. However, the social psychology of contemporary digital piety in Bangladesh cyberspace, who are mostly moderate Muslims and middle-class men, is, to some degree, different and unique in nature those are discussed in brief.

Spiritual pacification: Apart from all the ills and politics of religion, Islam is a complete way of life to many of its followers to achieve spiritual appeasement and heavenly feelings. Since religion has been accommodated in cyberspace, the devotees of Islam are also expressing their loyalty toward their belief by practicing essential religious rites. In cybersociety, Muslims, who are solely in search of the Islamic holiness and the mercy of Allah apart from any dogmatism what we call Quranic teachings, voice their inner fidelity to Islam that helps to find out same- minded individuals who together subsequently form diverse religious clans, interact within groups, and establish intergroup communication (Rahman, 1963).

Individuals in such factions tend to be sober and sympathetic to the other believers as they patronage peace and prosperity, neither segregation nor conflict. Online discourse on Islamic issues often leads to refine and produce healthier doctrines for society as well as humankind (Bunt, 2009). In other ways, in conciliating inner evils and harmful instincts, cyber-Islam is working as one of the finest instruments in Bangladesh provides a strong bonding among spiritual Sufi-minded or Falsafa (Islamic philosophy) influenced Muslim people (Horten, 2018).

Conformity and cohesion: What have been ignored widely in study of religious psychology is the importance of conformity and cohesion among individuals in each society. In general, 
people are motivated by their peers, and to them, alikeness bears meaning in life. Eminent sociologist Emile Durkheim designated religion as a functional source of social cohesion stating religion as "a unified system of beliefs and practices relative to sacred things, that is to say, things set apart and forbidden-beliefs and practices which unite into one single moral community" (Durkheim, 2008). It knits social individuals together through a common shared story as a thread, Harari claims (Harari, 2018).

Following the idea, no one in Bangladesh cybersociety usually want to be different as well as alien to their social community and context because it threatens one's identity and status within a society. Therefore, fearing of being excluded, individuals often imitate their peers' behavior in either subconscious or nonconscious manner which is in psychology known as Chameleon Effect (Chartrand and Bargh, 1999). Seculars and atheists who negate and reprimand Islam, for an example, are extremely marginalized and treated awfully in this Bangladesh traditional Muslim society. On the other hand, individuals' blind self is highly depended on how others are evaluating them so that opinions from community members are considered highly significant for a person (Luft \& Ingham, 1955). Thus, to be like the other community members and belong to a "Muslim society", individuals often perform according to the unseen social manuscript in public spaces as well as in digital media upholding religious sentiments.

Identity and projection of self: To know who one is, individuals return to their sociocultural roots. In this regard, religion has often been pronounced as the most suitable identity to the people of Bangladesh. Political Islam and religious nationalism helped Islam to establish a deep root into Bangladesh society, and became an unavoidable component of public life. Thereby, in identity construction, Islam plays a decisive role here. As a collectivistic culture, person's identity is heavily influenced by his group membership which is in fact offers a sense of self and belongingness, according to Zygmunt Bauman (Ammerman, 2003). Hence, Bangladesh netizens have also been in constant search of their social and individual identity in cyberspace too which fits best into their social atmosphere. Thereafter, most often they accept religious identity evaluating relative consequences.

Individuals want recognition of their peers. To be prominent and adored in society, the contribution of digital media is immense. In virtual spaces, identity of a person is reproduced. Reconstructing new identity, a fraud as a netizen could easily persuade others in his piousness and philanthropic virtue, no one would object. Thus, projecting a positive self in 
cyberspace by self-censoring and tailoring self, individuals get enough recognition that shape their self- esteems and self-identity. Sometimes, individuals rediscover their hidden self while representing themselves in virtual (Bell, 2001). As people are naturally or manually submissive to religion so that someone's determination toward shared belief of a community earns the members' respects and applauses in Bangladesh cyberculture.

Ultra-super ego and status maintenance: People who are originally callous about their religio-cultural practices are nevertheless becoming serious devoted guardian of their faith in virtual. This mere disguise which Freud would call "ultra-superego". Why some people use to be more innocent-like-being in virtual is undoubtedly linked with the person's real-life gain. Massive socio-political benefits encourage many individuals to pretend to be a devotee. It amplifies social status with even no harm at all. However, in so-called Islamic society of Bangladesh, religion in some cases has become an efficacious ladder to reach to the zenith of prestige and respect. Till date, an Imam gets more admiration and recognition in Bangladesh society than a teacher does (Ovi, 2018).

Reception and rejection of ideas: Two tiers of people are dominating Bangladesh digital public sphere who are fostering digital piety there. Firstly, the modernizers who belong to the first category. Filtering and accessing properly, these people are willing to embrace new ideas and beliefs received through digital communication with keenness. They are the key agent of social transformation. In contrast, the traditionalists are preventive in nature, stand against changes, and favor the existing social practices and customs. In cyberspace, these people show up their popular fervor of preserving so-called traditional vigor, history and belief rejecting newness. However, when contradictions happen between prior religious belief and a new but apparently logical one, the modernizers accept and transport the comparatively better one, whereas the traditionalists severely suffer from mental inconsistency (Griffin, 2012). They then either take firm position on their former stance, or acquire new knowledge related to this belief to counter and outweigh the new belief, or face and accept some selective aspects of the new idea that do not violate their predispositions and that reinforce their existing belief (McLeod, 2018). All these actions are taken to mitigate psychological contradiction.

\section{Digital Piety and Social Unrest}

Online religious community not only uphold and circulate their religious belief and worldview but also often have the determination to force and attribute their own ideology 
upon others. Thus, a chaotic situation develops. Not every Muslim has enough compassion toward other believers, and they deny the idea of peaceful religious coexistence. Such religious orthodox people create a fear-mongering situation in virtual world that often overflowed and sabotage real-life cohabitation. Bangladesh has been enduring continuous social unrests due to practicing radical religious behavior by many in cyberspace. Thus, online extremism is soaring drastically (Minority Rights Group International, 2016). Ramu Violence in 2012 on Buddhists, attack on Hindus in Pabna 2013, attack on Hindus in Comilla in 2013, Nasirnagar Violence in 2016 on Hindus, Thakurpara attack on Hindus in 2017 are some remarkable incidents of online-initiated communal violence unleashed upon religious minorities by fanatic Muslims, although the list is quite long (RT, 2012; Topu, 2013; The Times of India, 2014; Manik, 2016, Badal, 2017).

A commonplace but surprising plot has been unearthed behind each of these violent offenses. The Muslim perpetrators in guise of Hindus or Buddhists create social profiles and distribute hate speeches against Islam from those profiles. Most of the communal contents are either doctored photos or constructed speech. These provoke mass hysteria to rise against religious minorities, and amid such situations, any attempt to unravel the covert picture to assuage the fury of Muslims has been seen absent. On the other hand, recruiting Jihadi, online has been being used by extremists' group from the last few years. Following these ins and outs, The Guardian entitled internet as the "biggest breeding ground for violent extremism" (Travis, 2012). Thereby, in nourishing social unrest and confrontational politics, backed up by evidences, it can firmly be stated that digital piety is not only an indication of free religious expression but also a major driving force of disrupting the communal harmony.

\section{Conclusion}

No panacea exists to heal all the sickness dwelling amid human societies. Muslim dominated society in Bangladesh often has been suffering from communal malice in digital age. Cyberspace as a parallel reality alters one's identity and reconstruct a new "self". Hence, it is not perplexing if a crook is found "devotional" in digital forum. Real people from tangible world are shifting into cyberspace. Religion too would not possibly able to continue its operation without its devotees. Hence, it is following them where they belong, in digital space. Where there is sugar, there are bound to be ants. What the Bangladesh society is now experiencing is the digital showoff of exaggerative religious sentiment. Digital schismatics, in this respect, have failed to welcome the voice of religious minorities. Rather, dominant believers try to expel the subordinates from public discourse further reinforcing their 
dominance. On the other hand, debates and criticism of religious issues is implicitly prohibited addressing it "infidelity". Imposition of own opinion, practice and belief upon others in the name of religion is a growing tendency. All seem silent against such malpractice as everyone fears to be recognized as impious. As a result, an unbecoming consequence is looming amid this "muted" society. In fact, nothing is wrong with the God or even religion itself rather its ill- humored defenders and leaders who weaponize faith (Ovi, 2018).

Coexistence of the manifold beliefs and their followers would be ideal. However, tolerance has been evaporating increasingly. A new event has been rising: "we" versus "they". Muslim people are acting as the majority public holding a "we" sensation subduing the "they" who are the marginalized religious groups. Islam in Bangladesh, as it has been seen before from time to time, is just a makeshift mask for many individuals to earn social status, good name, multifarious aids, recognition, and so on as cited before. Digital Islam and piety, in such cases, has little to do with God but politics and power. To sustain national unity and peace within society, congruence between manifold communities is imperative, some religious pioneers are working on that. Meanwhile, according to Fragile States Index 2018, Bangladesh has the most declining society in terms of vivid socio-political failures, and disharmony and tension between its socio-cultural communities (The Fund for Peace, 2018). On the other hand, growing incidents of bigotry in Bangladesh from the last decade is nothing but a prologue of forthcoming tragedy if proper steps are not taken immediately. 


\section{Bibliography}

25,000 Muslim rioters torch Buddhist temples, homes in Bangladesh (September 30, 2012). $R T$. Retrieved from: $h t t p s: / / b i t . l y / 2 n b J Z s 4$

Ahasan, Nazmul (May 12, 2018). Why Bangladesh's inequality is likely to rise. The Daily Star. Retrieved from: https://bit.ly/2URjatA

Ammerman, Nancy T. (2003). Religious Identities and Religious Institutions. In Michele Dillon (ed.). The Handbook of the Sociology of Religion (pp. 207-224). London: Cambridge University Press.

Badal, Liakat Ali (November 10, 2017). Mob sets upon Hindu village over rumoured Facebook post. Dhaka Tribune. Retrieved from: https://bit.ly/2CqKQhK

Bangladesh Bureau of Statistics (2014). Bangladesh Population and Housing Census 2011. Bangladesh: Ministry of Planning, Government of the People's Republic of Bangladesh. Retrieved from: https://bit.ly/2ruGSOe

Bangladesh Telecommunication Regulatory Commission (October, 2018). Internet

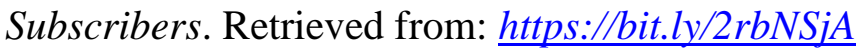

Banglapedia: National Encyclopedia of Bangladesh (December 19, 2018). Six-point Programme. Retrieved from: https://bit.ly/2CoPBsl

Banglapedia: National Encyclopedia of Bangladesh (December 19, 2018). Twenty-One Point Programme. Retrieved from: https://bit.ly/2EFAfAU

Banglapedia: National Encyclopedia of Bangladesh (December 19, 2018). Eleven Points Programme. Retrieved from: https://bit.ly/2EK9kFO

Bauwens, Michel (1996). Spirituality and Technology: Exploring the Relationship. First Monday, 1 (5), doi: http://dx.doi.org/1.10.5210/fm.v1i5.496.

Bell, David (2001). An Introduction to Cybercultures. London: Routledge. pp. 117-118

Bunt, Gary R. (2009). iMuslims: Rewiring the House of Islam. Chapel Hill: The University of North Carolina Press. pp. 8-11

Campbell, Heidi A. (2010). When Religion Meets New Media. London: Routledge. pp. 19-25

Carlisle, Clare (December 02, 2013). Is religion based on fear? The Guardian. Retrieved from: https://bit.ly/2HxNkKo

Chancery Law Chronicles Bangladesh (CLCBD) (June 06, 2011). The Constitution (Eighth Amendment) Act, 1988. Retrieved from: https://bit.ly/2Sfl5qb

Chartrand, T. L., \& Bargh, J. A. (1999). The chameleon effect: The perception-behavior link and social interaction. Journal of Personality and Social Psychology, 76(6), 893910. doi: http://dx.doi.org/10.1037/0022-3514.76.6.893

Chatterji, Joya (1994). Bengal Divided: Hindu communalism and partition, 1932-1947. London: Cambridge University Press. p. 83

Durkheim, Emile (2008). The Elementary Forms of the Religious Life (J. W. Swain, Trans). New York: Dover Publications, Inc. p. 47

Government of Bangladesh (1972). The First Constitution of the People's Republic of Bangladesh. Dhaka: Govt. of Bangladesh. pp. 11-12 Retrieved from: https://bit.ly/2BsmEKc 
Graner, Elvira, Yasmin, Fatema S., \& Aziz, Syeda S. (October, 2012). Giving Youth a Voice: Bangladesh Youth Survey 2011. Dhaka: Institute of Governance Study, BRAC University. pp-79-80

Griffin, M. (2012). A First Look at Communication Theory ( $8^{\text {th }}$ ed.). New York: McGraw Hill. pp. 289-194

Harari, Yuval Noah. (2018). 21 Lessons for the $21^{\text {st }}$ Century. London: Jonathan Cape. pp. 127-138

Hasan, Maidul (1986). Muldhara '71 ( $2^{\text {nd }}$ ed.). Dhaka: The University Press Limited. p. 211

Hindu households, temple attacked in Bangladesh (May 05, 2014). The Times of India. Retrieved from: https://bit.ly/2EwEyyq

Horten, M. (December 19, 2018). 'Falsafa'. In M. Th. Houtsma, T.W. Arnold, R. Basset, \& R. Hartmann (ed.). Encyclopedia of Islam (1913-1936). doi:

http://dx.doi.org/10.1163/2214-871X_ei1_SIM_2269

Hossain, Akhand Akhtar (2012). Islamic Resurgence in Bangladesh's Culture and Politics: Origins, Dynamics and Implications. Journal of Islamic Studies, 23 (2), 165-198. doi: https://doi.org/10.1093/jis/ets042

Jamal, Eresh Omar (December 19, 2017). Why is youth extremism on the rise? The Daily Star. Retrieved from: https://bit.ly/2EJK2Gt

Jones, Marcus (January 29, 2015). Church attendance dominated by middle class. Premier. Retrieved from: https://bit.ly/2POjTIe

Jordan, Tim (1999). Cyberpower: The culture and politics of cyberspace and the Internet. London: Routledge. pp. 65-66

Luft, J., \& Ingham, H. (1955). “The Johari window, a graphic model of interpersonal awareness". Proceedings of the Western Training Laboratory in Group Development. Los Angeles: University of California, Los Angeles Extension Office.

Manik, Julfikar Ali, \& Barry, Ellen (November 02, 2016). Hindu temples and homes in Bangladesh are attacked by Muslim crowds. The New York Times. Retrieved from: https://nyti.ms/2GzIvoO

Majumdar, Shantanu (2016). Secularism and anti-secularism. In Ali Riaz \& M. S. Rahman (ed.). Routledge Handbook of Contemporary Bangladesh (40-51). London: Routledge.

McKinnon, A. M. (2005). Reading "Opium of the People": Expression, Protest and the Dialectics of Religion. Critical Sociology, 31 (1-2), 15-38. doi: http://dx.doi.org/10.1163/1569163053084360.

McLeod, S. A. (2018). Cognitive dissonance. Retrieved from: https://bit.ly/2t2YT5x

Middle-class burgeoning (February 04, 2018). Daily Sun. Retrieved from: https://bit.ly/2QFFdov

Minority Rights Group International (2016). Under Threat: The challenges facing religious minorities in Bangladesh. Sweden: Minority Rights Group. pp. 21-22

Nietzsche. Friedrich (1974). The Gay Science (Walter Kaufmann, Trans.). New York: Vintage Books. p. 181

No Hindus will be left in Bangladesh after 30 years: professor (November 22, 2016). The Hindu. Retrieved from: https://bit.ly/2A7T1Ou 
Ovi, Sayeed (October 08, 2018). Rise of digital piety in Bangladesh: How extremism found a new nest cyberspace? The Independent. Retrieved from: https://bit.ly/2E5Tp4s

Ovi, Sayeed (October 31, 2018). Digital religion and "othering" the co-cultures. The Asian Age. Retrieved from: https://bit.ly/2OZL9b3

Prensky, Marc (October 2001). Digital Natives, Digital Immigrants. On the Horizon, 9 (5), 16. doi: http://dx.doi.org/10.1108/10748120110424816.

Rahman, Syedur (1963). An Introduction to Islamic Culture and Philosophy (3 ${ }^{\text {rd }}$ ed.). Dhaka: Mullick Brothers. pp. 35-45

Rogers, Everett M. (1983). Diffusion of Innovations ( $3^{\text {rd }}$ ed.). New York: The Free Press. pp. 247-250

Russel, Bertrand (1996). Why I am Not A Christian. London: Routledge. pp. ix-18

The Fund for Peace (2018). Fragile States Index 2018. Washington: The Fund for Peace (FFP). p. 39 Retrieved from: https://bit.ly/2Qzs3ss

Topu, Ahmed H. K. (November 03, 2013). Hindus attacked in Pabna. The Daily Star.

Retrieved from: https://bit.ly/2LzigOl

Travis, Alan (February 06, 2012). Internet biggest breeding ground for violent extremism, ministers warn. The Guardian. Retrieved from: https://bit.ly/2EL1OJV

Weber, Max (1949). The Social Psychology of World Religions. In H. Gerth, \& C. W. Mills (Eds). From Max Weber: Essays in Sociology (pp. 268-279). New York: Oxford University Press.

World Bank (2016). Individuals Using the Internet. Retrieved from: $\underline{\text { ttps://bit.ly/2BGjdB8 }}$

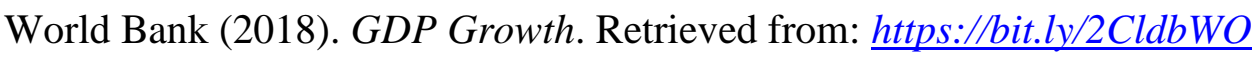

Xypolia, Ilia (2016). Divide et Impera: Vertical and Horizontal Dimensions of British Imperialism. Critique: Journal of Socialist Theory, 44 (3), 221-231. doi. http://dx.doi.org/10.1080/03017605.2016.1199629. 